\title{
Determinan Diare Berdasarkan Pilar Sanitasi Total Berbasis Masyarakat
}

\author{
Mei Ahyanti", Yeni Rosita \\ Bandar Lampung 35145, Indonesia \\ *Corresponding author: meiahyati@poltekkes-tjk.ac.id \\ Info Artikel:Diterima 23 Mei 2021 ; Direvisi 24 Januari 2022 ; Disetujui 24 Januari 2022 \\ Tersedia online : 28 Januari 2022 ; Diterbitkan secara teratur : Februari 2022
}

Jurusan Kesehatan Lingkungan, Politeknik Kesehatan Kemenkes Tanjungkarang, Jl. Soekarno Hatta No. 6

Cara sitasi (Vancouver): Ahyanti M, Rosita Y. Determinan Diare Berdasarkan Pilar Sanitasi Total Berbasis Masyarakat. Jurnal Kesehatan Lingkungan Indonesia [Online]. 2022 Jan;21(1):1-8. https://doi.org/10.14710/jkli.21.1.1-8.

\begin{abstract}
ABSTRAK
Latar belakang: Indonesia, bahkan dunia masih memikili masalah kesehatan serius yaitu diare, kasusnya meningkat dari tahun 2016-2018. Distribusi kasus di Kabupaten Lampung Selatan terbanyak pada Desa Taman Sari Wilayah Kerja Puskesmas Penengahan. STBM dinyatakan sebagai proyek yang dapat membawa perubahan besar terhadap kejadian diare. Penelitian bertujuan mengetahui determinan diare berdasarkan pilar STBM.

Metode: penelitian ini dilakukan dengan rancangan cross sectional. Populasi adalah penduduk Desa Taman Baru Kecamatan Penengahan Kabupaten Lampung Selatan berjumlah 267 kepala keluarga (KK), dan semuanya dijadikan objek penelitian. Pengumpulan data melalui wawancara dan pengamatan menggunakan instrumen yang merujuk pada instrumen Kemenkes RI. Data dianalisa secara bivariat dengan chi square. Pengolahan dan analisa data menggunakan program komputer.

Hasil: masyarakat telah memiliki pengetahuan yang baik tentang STBM, akan tetapi belum diterapkan dengan benar. Pemaparan yang dilakukan petugas belum memberikan dampak terhadap penurunan angka diare. Hal ini dapat diasumsikan bahwa informasi yang disampaikan oleh petugas tidak sampai kepada masyarakat. Metoda penyampaian yang kurang tepat atau model pemberdayaan masyarakat yang kurang menyebabkan masyarakat tidak tergugah untuk melakukan perubahan perilaku hidup sehat.

Simpulan: faktor dominan yang berhubungan dengan diare adalah penerapan pilar STBM. Perlu dilakukan strategi promosi kesehatan untuk penerapan pilar STBM dan peningkatan pengetahuan masyarakat tentang pencegahan diare. Penelitian lanjutan dapat dilakukan berkaitan dengan model yang tepat dan efektif dalam penyampaian informasi kepada masyarakat dengan dukungan tokoh masyarakat.
\end{abstract}

Kata kunci: Diare; model; pilar; promosi kesehatan; STBM

\section{ABSTRACT}

Title: Determinants Of Diarrhea Based On Pillars Of Total Community-Based Sanitation

Background: Diarrhea remains a health problem around the world, including in Indonesia. Cases increased from 2016 to 2018. The distribution of cases in South Lampung district is mainly in Taman Sari village, the working area of Puskesmas Penengah. STBM is considered a program that could make a big difference in diarrhea incidence. This study aimed to identify determinants of diarrhea according to the STBM pillars.

Method: the research was conducted with a cross-sectional design. The population is 267 families who are residents of Taman Baru Village, and all of them are used as the research object. Data were collected through interviews and observations using instruments referencing the instruments of the Ministry of Health of the Republic of Indonesia. Data were analyzed by chi-square statistical test using a computer application. 
Result: research shows that people have good knowledge about STBM, but it has not been implemented properly. The officer's exposure has not had an impact on reducing diarrhea rates. It can be assumed that the information submitted by the officers did not reach the public. Inappropriate delivery methods or community empowerment models that are less likely to cause people to not be moved to make changes to healthy living behavior

Conclusion: the dominant factor associated with diarrhea is the implementation of the STBM pillar. There is a need to implement health promotion strategies to implement the STBM pillars and increase public awareness of diarrhea prevention. With the support of community leaders, further research can be conducted on appropriate and effective modalities for providing information to the public.

Keywords: Dhiarrhea; models; pillars; health promotion; STBM

\section{PENDAHULUAN}

Diare menempati posisi kedua di dunia sebagai penyebab kematian bayi bayi lima tahun (Balita). Seperlima anak penderita diare meninggal karenanya, akibatnya sekitar 1 juta 500 ratus ribu Balita meninggal karena diare setiap tahun. Angka kejadian dan mortalitas yang tinggi akibat diare masih menjadi problema bagi kesehatan di masyarakat negara-negara berkembang seperti Indonesia. Wabah (KLB) diare sering terjadi dan memiliki angka kematian (CFR) tinggi. Tahun 2008 pada 69 kecamatan di Indonesia telah terjadi kasus sebesar 8133. Kejadian ini mengakibatkan 239 kematian (CFR 2,94\%). Tahun 2009 terdapat total 5.756 kasus dan 100 kematian (CFR 1,74\%). Pada tahun 2010 diare menyerang 4204 penderita dengan 73 kematian (CFR 1,74\%). Kasus tahun 2010 ini berjangkit di 33 kecamatan. Cita-cita Millenium Development Goals (MDGs) Goal ke-4 adalah tahun 1990 sampai tahun 2015 adalah penurunan $2 / 3$ angka kematian anak. ${ }^{1}$ Peningkatan kasus diare telah terjadi tahun 2016 hingga 2018 di Lampung Selatan. Kasus terbanyak di wilayah Puskesmas Rawat Inap Kecamatan Penengahan. ${ }^{2}$ Tahun 2016 terjadi 2060 kasus, tahun 2017 terjadi 2060 kasus, tahun 2018 terjadi 2249 kasus. $^{3}$

Penyebab angka kematian tinggi ini salah satunya karena terbatasnya pengetahuan penduduk tentang cara cuci tangan yang benar. Cara yang paling tepat dan cepat untuk mencegah diare sekaligus menyelamatkan hidup anak Indonesia adalah melalui CTPS yang benar. ${ }^{4}$ Kebiasaan CTPS akan berkontribusi penting bagi pencapaian MDGs. Ini bisa jadi salah satu tantangan pencapaian pembangunan Millenium. ${ }^{5}$ Sebuah studi oleh Badan Kesehatan Dunia (WHO) menunjukkan kebiasaan cuci tangan pakai sabun (CTPS) telah memberikan kontribusi dalam mencegah diare hingga $45 \%{ }^{5}$ Mencuci tangan dianggap sebagai langkah penting dalam mencegah meluasnya pemencaran penyakit bawaan makanan dengan mengurangi kontaminasi silang di antara tangan, permukaan kerja, dan makanan. ${ }^{6}$ Untuk mencegah terjadinya infeksi dan mengurangi dampak kesehatan sangat penting membuat fasilitas lebih aman untuk masyarakat. ${ }^{7}$

STBM mewakili perubahan besar untuk proyek sanitasi dan program dalam menghentikan buang air besar (BAB) sembarangan di masyarakat, bahkan ketika toilet individu dibangun belum tentu sepenuhnya higienis. ${ }^{8}$ Rencana kerja STBM merupakan upaya untuk mencapai tujuan Millenium (7c) 2015, yaitu secara berkelanjutan meningkatkan kemudahan mendapatkan air minum dan fasilitas sanitasi dasar bagi seperdua penduduk yang masih kesulitas mendapatkannya. BPS dan Kementerian Pekerjaan Umum menegaskan capaian akses sanitasi yang memenuhi syarat bagi masyarakat Indonesia tahun 2012 sebesar 57,35\% dari target MDG's. ${ }^{9}$ STBM di lounching sebagai salah satu upaya memenuhi target. Lima pilar utamanya adalah buang hajat di jamban, CTPS, pengelolahan makanan dan minuman, pengelolaan sampah dan limbah cair tingkat rumah tangga. Cuci tangan masih menjadi tujuan penting dalam meningkatkan kesehatan. Hal ini disebabkan perilaku CTPS di masyarakat masih rendah. Padahal kebiasaan atau perilaku bersih dengan CTPS efektivitas mengurangi penyebaran penyakit menular, seperti diare. 5 pilar STBM belum terlaksana dengan baik, masih banyak masyarakat yang melalukan praktik BAB sembarangan dan tidak mengelola sampah. Kondisi ini menyebabkan kasus diare menjadi tinggi.

Banyak penelitian telah dilakukan untuk melihat efek spesifik intervensi kebersihan tangan berbasis sekolah pada infeksi dan ketidakhadiran di sekolah. Penelitian berfokus pada penerapan atau pelaksanaan 5 Pilar STBM oleh masyarakat sehingga dapat mencegah terjadinya diare sebagai novelty dari penelitian ini. Tujuan penelitian adalah mengetahui determinan diare berdasarkan pilar STBM.

\section{MATERI DAN METODE}

Penelitian dengan jenis kuantitatif dengan desain cross sectional (potong lintang) diperkuat kualitatif untuk melihat hubungan dukungan tokoh masyarakat dan pemaparan petugas kesehatan serta penerapan STBM oleh masyarakat dengan kejadian diare. Penelitian dilaksanakan selama 6 bulan (Maret sampai Agustus 2020). Obyek penelitian adalah seluruh kepala keluarga di Desa Taman Baru, berjumlah 267. Sebagai variabel dependent adalah kejadian diare, sedangkan variabel independen adalah pengetahuan tentang STBM, dukungan tokoh masyarakat, paparan petugas kesehatan dan penerapan pilar STBM. Data dikumpulkan dengan cara observasi 
menggunakan instrument checklist dan wawancara menggunakan kuesioner. Tidak dilakukan uji validitas dan reliabilitas instrument pengumpulan data karena instrument disusun merujuk pada instrument STBM Kemenkes RI. Data yang terkumpul diolah dan dianalisa secara univariat menggunakan tabel distribusi frekwensi, serta uji hipotesis menggunakan uji chi square dan regresi logistic. Penelitian ini telah mendapatkan etical clearance penelitian yang dikeluarkan oleh Komisi Etik Politeknik Kesehatan Kemenkes Tanjungkarang dengan nomor 231/KEPK$\mathrm{TJK} / \mathrm{III} / 2020$.

\section{HASIL DAN PEMBAHASAN}

Distribusi responden berdasarkan variabel penelitian disajikan pada tabel 1 .

Tabel 1. Faktor-faktor yang berhubungan dengan Diare di Desa Taman Baru Kecamatan Penengahan Kabupaten Lampung Selatan Provinsi Lampung tahun 2020

\begin{tabular}{|c|c|c|c|c|c|c|c|}
\hline \multirow[t]{2}{*}{ No. } & \multirow[t]{2}{*}{ Variabel } & \multirow{2}{*}{$\begin{array}{c}\text { Diare } \\
\mathrm{n}=267 \\
\end{array}$} & \multirow{2}{*}{$\begin{array}{c}\text { Tidak Diare } \\
\mathrm{n}=267\end{array}$} & \multirow{2}{*}{ p-value } & \multirow{2}{*}{ OR } & \multicolumn{2}{|c|}{$95 \%$ CI } \\
\hline & & & & & & Lower & Upper \\
\hline \multirow[t]{3}{*}{1.} & Pengetahuan & & & \multirow{3}{*}{$0,020 *$} & \multirow{3}{*}{2,674} & \multirow{3}{*}{1,217} & \multirow{3}{*}{5,875} \\
\hline & Kurang Baik & $19(63,3 \%)$ & $11(36,7 \%)$ & & & & \\
\hline & Baik & $93(39,2 \%)$ & $144(60,8 \%)$ & & & & \\
\hline \multirow[t]{4}{*}{2.} & Pemaparan & & & & & & \\
\hline & kesehatan & & & & & & \\
\hline & Tidak mendapatkan & $9(60,0 \%)$ & $6(40,0 \%)$ & \multirow{2}{*}{0,234} & \multirow{2}{*}{2,170} & \multirow{2}{*}{0,749} & \multirow{2}{*}{6,282} \\
\hline & Mendapatkan & $103(40,9 \%)$ & $149(59,1 \%)$ & & & & \\
\hline \multirow[t]{3}{*}{3.} & Perilaku BAB & & & & & & \\
\hline & BABS & $9(60,0 \%)$ & $6(40,0 \%)$ & \multirow{2}{*}{$0,000 *$} & \multirow{2}{*}{3,317} & \multirow{2}{*}{1,978} & \multirow[b]{2}{*}{5,563} \\
\hline & Tidak BABS & $52(31,1 \%)$ & $115(68,9 \%)$ & & & & \\
\hline \multirow[t]{3}{*}{4.} & Perilaku CTPS & & & \multirow{3}{*}{0,000} & \multirow{3}{*}{3,084} & \multirow{3}{*}{1,812} & \multirow{3}{*}{5,249} \\
\hline & Tidak CTPS & $52(60,5 \%)$ & $34(39,5 \%)$ & & & & \\
\hline & CTPS & $52(33,1 \%)$ & $115(66,9 \%)$ & & & & \\
\hline \multirow[t]{5}{*}{5.} & Pengelolaan Makanan & & & & & & \\
\hline & Minuman & & & & & & \\
\hline & $\begin{array}{l}\text { Tidak dilakukan } \\
\text { pengelolaan }\end{array}$ & $2(100 \%)$ & $0(0 \%)$ & \multirow{3}{*}{0,175} & \multirow{3}{*}{2.409} & \multirow{3}{*}{0,088} & \\
\hline & Dilakukan & $110(4150 /)$ & $155(5850)$ & & & & 2,779 \\
\hline & pengelolaan & $110(41,5 \%)$ & $155(58,5 \%)$ & & & & \\
\hline 6. & $\begin{array}{l}\text { Pengelolaan sampah } \\
\text { rumah tangga }\end{array}$ & & & & & & \\
\hline & $\begin{array}{l}\text { Tidak melakukan } \\
\text { pengelolaan }\end{array}$ & $101(45,5 \%)$ & $121(55,5 \%)$ & 0015 & 580 & 1214 & 5250 \\
\hline & $\begin{array}{r}\text { Melakukan } \\
\text { pengelolaan }\end{array}$ & $11(24,4 \%)$ & $34(75,6 \%)$ & 0,015 & 2,500 & 1,244 & J,5J0 \\
\hline 7. & $\begin{array}{l}\text { Pengelolaan limbah } \\
\text { rumah tangga }\end{array}$ & & & & & & \\
\hline & Tidak dikelola & $110(41,8 \%)$ & $153(58,2 \%)$ & 1000 & 0719 & 0.100 & 5182 \\
\hline & Dikelola & $2(50,0 \%)$ & $2(50,0 \%)$ & 1,000 & 0,119 & & \\
\hline 8. & Penerapan STBM & & & & & & \\
\hline & Tidak Menerapkan & $68(59,6 \%)$ & $48(40,4 \%)$ & $0,000 *$ & 3.662 & 2,194 & 6,113 \\
\hline & Menerapkan & $44(28,8 \%)$ & $109(71,2 \%)$ & 0,000 & 5,002 & 2,194 & $0,11 J$ \\
\hline
\end{tabular}

Ket : (signifikan)

Pada tabel 1 terlihat, 63,3\% rensponden yang memiliki pengetahuan kurang baik, terdapat $63,3 \%$ menderita diare dan 36,7\% tidak diare. Hasil uji chi square menunjukkan $\mathrm{p}$ value $0,020<\alpha(0,05) \mathrm{OR}=$ 2,674 (CI 95\% 1,217-5,875), dapat disimpulkan bahwa hipotesis gagal tolak, artinya terdapat hubungan bermakna antara pengetahuan dengan kejadian diare. Responden dengan pengetahuan kurang baik berisiko 2,674 kali menderita diare dibanding renponden dengan pengetahuan baik.

Hasil penelitian ini menunjukan sebagian besar masyarakat mempunyai pengetahuan yang baik mengenai STBM meliputi pengetahuan tentang buang air besar yang aman, CTPS yang benar, pengelolaan makanan minuman, pengelolaan sampah dan limbah cair di rumah tangga. Pengetahuan masyarakat berasal dari informasi yang diterima baik dari sekolah maupun media masa dan peran aktif petugas kesehatan dalam menambah pengetahuan masyarakat. Untuk melakukan tindakan tertentu, pengetahuan penting dimiliki. Pengetahuan yang baik terhadap suatu kondisi akan membuat seseorang cenderung berbuat atau berperilaku sesuai pengetahuannya. Jika pengetahuannya baik, maka kecenderungan seseorang 
akan mengarah pada perilaku baik. Demikian sebaliknya, jika pengetahuan seseorang kurang baik, maka kecenderungan orang tersebut akan mengarah kepada perilaku yang kurang baik.

Hasil uji statistik menyimpulkan ada hubungan bermakna antara pengetahuan dengan diare. Penelitian ini diperkuat penelitian lain, bahwa pengetahuan berhubungan secara signifikan dengan kejadian diare. ${ }^{10-12}$ Pengetahuan yang kurang tentang penanganan diare juga menjadi penyebab terjadinya kesakitan diare. ${ }^{13}$ Pengetahuan yang diperoleh akan terserap kedalam pemikiran dan menimbulkan pemahaman. Pemahaman tentang penyakit diare, cara pencegahan dan cara pengobatan akan mengarahkan masyarakat bertindak. Tindakan yang dilakukan sebagai upaya agar dirinya dan keluarganya terhindar dari penyakit diare.

Tabel 1. menjelaskan bahwa pada kelompok responden yang tidak mendapatkan pemaparan petugas kesehatan, terdapat $60,0 \%$ menderita diare dan $40,0 \%$ tidak diare. Sedangkan pada kelompok responden menyatakan mendapatkan pemaparan dari petugas kesehatan terdapat $40,9 \%$ menderita diare dan $59,1 \%$ tidak menderita diare. Hasil uji statistik menunjukkan $p$ value $0,235>\alpha(0,05)$. Dari hasil ini disimpulkan bahwa hipotesis ditolak yang artinya tidak terdapat hubungan yang bermakna antara pemaparan dari petugas kesehatan dengan kejadian diare.

Pada kelompok responden yang tidak mendapat pemaparan dari petugas kesehatan terdapat $60,0 \%$ menderita diare dan $40,0 \%$ tidak mederita diare, sedangkan yang mendapat pemaparan dari petugas kesehatan terdapat 40,9\% menderita diare dan 59,1\% tidak menderita diare. Petugas kesehatan adalah orang yang dapat dipercaya oleh masyarakat dalam menyampaikan informasi kesehatan. Petugas kesehatan merupakan pejuang terdepan dalam upaya pengedalian kejadian suatu penyakit. Petugas kesehatan memiliki tugas dan tanggungjawab untuk menyampaikan informasi tentang suatu penyakit dan cara pencegahannya.

Hasil analisa secara bivariat memperoleh $p$ value $=0,234>\alpha$, artinya tidak terdapat hubungan yang bermakna antara pemaparan petugas kesehatan dengan diare. Hasil ini bertolak belakang dengan penelitian terdahulu yang menyatakan paparan petugas kesehatan berpengaruh secara langsung terhadap perilaku kesehatan masyarakat. ${ }^{14,15}$ Dalam penelitian ini masih terdapat masyarakat yang tidak mendapatkan pemaparan informasi (15\%). Kegiatan yang dilaksanakan oleh petugas sudah baik, namun tetap perlu dipertahankan serta ditingkatkan. Peningkatan pemaparan informasi kesehatan tidak hanya melalui kegiatan penyuluhan rutin, dapat juga menggunakan leaflet maupun langsung dari rumah kerumah. Peningkatan kegiatan dapat dilaksanakan pada $15 \%$ masyarakat yang belum memperoleh pemaparan informasi kesehatan. Namun hasil uji statistik menyatakan tidak ada hubungan antara pemaparan petugas dengan diare. Pada penelitian ini mayoritas masyarakat telah mendapatkan pemaparan informasi tentang kesehatan khususnya STBM dalam upaya pencegahan diare (85\%).

Setelah mendapatkan pemaparan dari petugas tentang STBM, harapannya adalah masyarakat melakukan praktik PHBS sehingga berdampak pada menurunnya angka kejadian diare. Namun berbeda dengan Desa Taman Baru, pemaparan yang dilakukan petugas belum memberikan dampak terhadap penurunan angka diare. Hal ini dapat diasumsikan bahwa informasi yang dipaparkan oleh petugas tidak sampai kepada masyarakat. Bisa jadi masyarakat tidak memahami materi, memiliki pemahaman berbeda tentang informasi tersebut karena metoda penyampaian kurang tepat atau bahkan model pemberdayaan masyarakat yang masih kurang sesuai sehingga masyarakat tidak tergugah untuk melakukan perubahan perilaku hidup sehat. Melihat hasil tersebut, perlu dilakukan penelitian tentang model yang tepat dan efektif dalam menyampaikan informasi ke masyarakat dengan dukungan tokoh masyarakat setempat.

Penerapan pilar 1 hingga pilar 5 selanjutnya digabungkan menjadi penerapan pilar STBM. Pada kelompok responden yang tidak menerapkan, terdapat $59,6 \%$ menderita diare dan 50,4\% tidak diare. Sedangkan pada kelompok responden yang menerapkan STBM terdapat 28,8\% menderita diare dan $71,2 \%$ tidak diare. Hasil uji chi square menunjukkan $\mathrm{p}$ value $0,000<\alpha(0,05) \mathrm{OR}=3,663$ (CI 95\% 2,194-6,113), dapat disimpulkan bahwa hipotesis gagal ditolak yang artinya ada hubungan bermakna antara penerapan STBM dengan diare. Responden yang tidak menerapkan STBM berisiko 3,663 kali menderita diare dibanding responden yang menerapkan STBM di rumah tangganya.

Tabel 2. Model Prediksi Hubungan Pengetahuan, Paparan Petugas Kesehatan dan Penerapan 5 Pilar STBM dengan Diare 95\% C.I.for EXP(B)

\begin{tabular}{lcccrcrrr} 
& B & S.E. & Wald & df & Sig. & Exp(B) & Lower & \multicolumn{1}{c}{ Upper } \\
\hline pengetahuan & 1,307 & 0,440 & 8,848 & 1 & 0,003 & 3,697 & 1,562 & 8,749 \\
pemaparan & 1,140 & 0,595 & 3,666 & 1 & 0,056 & 3,125 & 0,973 & 10,035 \\
penerapan & 1,583 & 0,283 & 31,174 & 1 & 0,000 & 4,867 & 2,793 & 8,483 \\
Constant & $-2,769$ & 0,724 & 14,628 & 1 & 0,000 & 0,063 & & \\
\hline
\end{tabular}


Tabel 2. menjelaskan variabel yang paling dominan berpengaruh terhadap diare adalah penerapan STBM $p$ value $=0,000$ dan $O R=4,867$. Artinya setelah diuji secara bersamaan, penerapan pilar STBM memiliki pengaruh terbesar dalam kejadian diare di Desa Taman Baru, dengan besar risiko 4,867 kali. Selanjutnya dari ke-5 pilar STBM, yang berhubungan secara signifikan dan memiliki pengaruh terbesar adalah perilaku BABs dengan $p$ value $0,000 \mathrm{OR}=3,317$.

Penerapan STBM dilihat dari 5 pilar yaitu buang air besar (BAB), mencuci tangan, pengelolaan makanan minuman, pengelolaan sampah dan pengelolaan limbah cair yang dilakukan oleh anggota keluarga. Selanjutnya lima pilar tersebut digabungkan menjadi 1 kesatuan penerapan pilar STBM. Hasil analisis memperoleh responden dengan perilaku $\mathrm{BAB}$ sembarangan ada $60,0 \%$ yang menderita diare dan $40,0 \%$ tidak diare. Kelompok responden dengan perilaku tidak $\mathrm{BAB}$ sembarangan terdapat $31,1 \%$ menderita diare dan $68,9 \%$ tidak menderita diare. Hasil uji statistik menunjukkan $\mathrm{p}$ value $0,000<\alpha$ $(0,05)$, dapat disimpulkan bahwa ada hubungan signifikan antara perilaku BAB dengan kejadian diare. Hasil ini sejalan dengan penelitian lain yang melihat hubungan sanitasi lingkungan dengan angka kejadian diare pada balita di wilayah kerja Puskesmas Meuraxa. ${ }^{16}$

Beberapa penelitian yang sejalan menunjukkan hasil bahwa ada hubungan antara pengunaan jamban dengan kejadian diare $(p$ value $=0,015) .{ }^{17}$ Penerapan STBM aspek stop BAB Sembarangan (stop BABS) berdampak pada angka diare yang makin tinggi. ${ }^{18,19}$ Masyarakat yang berperilaku BABS memiliki risiko lebih tinggi untuk mengalami diare dan merupakan ancaman terhadap kejadian diare. ${ }^{20,21,22}$

Kenyataan di lapangan menemukan masyarakat memahami pentingnya pemanfaatan jamban tetapi tidak menerapkan buang air di jamban. Mereka tetap BAB di sembarang tempat seperti: di kebun dan di sungai. Artinya, perlu dilakukan upaya menciptakan kesadaran pada masyarakat bahwa perilaku BABS dapat mengganggu masyarakat lain dan menimbulkan penyakit. ${ }^{23}$ Masyarakat Desa Taman Baru belum semuanya memiliki akses terhadap jamban sehat. Oleh karena itu diperlukan sarana yang memadai yang ada di rumah masingmasing warga agar aksesnya mudah dan tidak merasa malu untuk menumpang pada jamban milik tetangga.

Kotoran yang dibuang secara sembarangan akan menjadi tempat hidup mikroorganisme pathogen dan mengundang vektor penyakit seperti lalat juga semut. Lalat yang hinggap pada kotoran kemudian akan hinggap pada makanan dan meninggalkan mikroba pathogen di kakinya pada makanan. Jika makanan itu dimakan oleh manusia maka akan menimbulkan sakit. Kotoran / tinja sebaiknya dibuang di tempat tertutup yang tidak dapat dijangkau oleh serangga sebagai vektor penyakit. Tempat pembuangan tinja yang aman adalah jamban leher angsa. Pada jamban leher angsa terdapat water sill yaitu air pada jamban leher angsa yang berfungsi menutup saluran pembuangan, sehingga kotoran terisolasi, tidak menimbulkan bau dan tidak terjamah oleh serangga. Praktik BAB di Desa Taman Baru masih dilakukan di sungai dan halaman belakang rumah. Praktik BABS ini menimbulkan bau yang mengundang lalat untuk datang. Jarak yang dekat antara rumah dengan tempat pembuangan kotoran memungkinkan lalat yang hinggap di kotoran akan masuk kerumah dan hinggap pada makanan. lalat meninggalkan kotoran pada makanan dan apabila dimakan oleh manusia akan berisiko terserang penyakit.

Tangan manusia merupakan salah satu portal of entry (jalan masuk) mikroorganisme ke dalam tubuh melalui mulut. Mikroorganisme ini dapat menjadi agent penyakit. Tujuan dari CTPS adalah mengusir dan mematikan mikroba yang berada di tangan dan sela-sela jemari menggunakan air dan sabun atau pun cairan lain. Hasil penelitian yang didapat memperlihatkan $p$ value $0,000<\alpha(0,05)$, artinya terdapat hubungan signifikan antara perilaku CTPS dengan kejadian diare. Penelitian lain juga menunjukan adanya pengaruh CTPS terhadap diare ${ }^{11}$. Kebersihan tangan berkontribusi terhadap kejadian diare dan menunjukkan peningkatan hingga $31,02 \%$, hasil analisis menemukan bahwa sub variabel yang berkontribusi terhadap kejadian diare pada bayi adalah cara cuci tangan. ${ }^{24}$

Cuci tangan menjadi perilaku penting untuk mencegah kejadian diare. CTPS dengan air mengalir pada saat-saat tertentu seperti saat akan makan, setelah memegang benda kotor, setelah berhubungan dengan tanah, setelah cebok atau menceboki anak, ketika akan menyuapi anak terbukti dapat menekan terjadinya penyakit diare. Deterjen yang terdapat pada sabun yang dituangkan dan digosokkan pada telapak tangan dan sela-sela jari akan membunuh mikroba yang menempel pada kulit tangan. Air mengalir akan membasuh mikroba dan kotoran yang berada di tangan sehingga terlepas dan tangan menjadi bersih.

Masyarakat Desa Taman Baru meski telah memiliki pengetahuan tentang pentingnya CTPS, masih ada yang tidak mempraktikannya. Pengetahuan yang dimiliki belum cukup untuk membuat masyarakat bertindak, perlu adanya pendampingan dari petugas kesehatan dan tokoh masyarakat dalam mengingatkan masyarakat tentang pentingnya CTPS. Masyarakat tidak mempraktikkan CTPS dengan alasan belum memiliki sarana CTPS. Kondisi ini dapat diatasi dengan pembuatan pancuran menggunakan ember yang diberi tutup dan kran atau memakai gallon yang telah dilengkapi dengan kran. Pancuran dan sabun dapat diletakkan di depan rumah, agar keluarga lebih mudah melakukan CTPS setelah bepergian atau memegang sesuatu yang kotor. Tangan yang bersih dan terbebas dari 
mikroba pathogen akan menghindarkan diri dari serangan penyakit.

Hasil analisis memperoleh $p$ value $0,175>\alpha$ $(0,05)$, pengelolaan makanan dan minuman di rumah tangga berhubungan dengan diare. Hal ini juga diungkap dalam beberapa penelitian bahwa pengelolaan air minum di tingkat rumah dan pengelolaan makanan di rumah tangga tidak berhubungan dengan kejadian diare. ${ }^{25,26}$ Hasil ini tidak sejalan dengan teori Kementerian Kesehatan pilar STBM PMM rumah tangga. Penting untuk menerapkan prinsip hygiene dalam PMM. Air yang di minum belum tentu memenuhi syarat kesehatan maka harus diolah. Demikian pula dengan bahan makanan, perlu dipilih, diolah, disimpan, diangkut dan disajikan dengan cara yang benar. Peraturan Menteri Kesehatan RI no. 3 tahun 2014 tentang STBM menyatakan bahwa PMM di rumah tangga bertujuan memperbaiki serta menjaga kualitas air minum yang berasal dari sumber air, dan dalam proses pengolahan makanan dan minuman senantiasa menerapkan prinsip higiene sanitasi pangan.

Diare yang disebabkan oleh air minum dan makanan yang tidak bersih seringkali berhubungan dengan mikroba dan bahan kimia yang masuk ke saluran pencernaan. Penularan diare dapat terjadi melalui mekanisme fecal-oral, antara lain air minum dan makanan yang terkontaminasi atau tercemar. ${ }^{27}$ Pada penelitian ini $99,3 \%$ masyarakat telah melakukan pengelolaan makanan minuman di tingkat rumah tangga dengan aman. Pengelolaan makanan yang aman dinilai dari penggunaan air yang dimasak terlebih dahulu sebelum diminum, air disimpan dalam wadah bersih dan tertutup rapat, tempat air minum dibersihkan setiap hari, makanan masak diletakkan dalam wadah tertutup dan bersih, dan bahan makanan dicuci terlebih dahulu sebelum diolah menggunakan air bersih yang mengalir.

Diperoleh informasi $93,6 \%$ masyarakat tidak melakukan pengelolaan sampah. Hasil uji mendapatkan $p$ value $0,087>\alpha(0,05)$, artunya tidak terdapat hubungan bermakna antara pengelolaan sampah di rumah tangga dengan kejadian diare. Hasil ini didukung oleh penelitian lain yang menyimpulkan bahwa tidak ada hubungan antara penerapan pengelolaan sampah rumah tangga (PSRT) sebagai salah satu pilar STBM dengan kejadian diare. ${ }^{28}$ Namun penelitian di Kabupaten Aceh besar bertentangan dengan penelitian ini. ${ }^{16,29}$

Dalam penanganan sampahnya, masyarakat Desa Taman baru melakukan penampungan didalam rumah, tetapi tidak dipisahkan antara sampah yang mudah membusuk dan sulit membusuk. Tidak adanya petugas pengangkut sampah menyebabkan masyarakat tidak dibuang sampah ke tempat pembuangan akhir. Sampah yang dikumpulkan selanjutnya dibuang ke sungai atau dibakar dihalaman rumah. Sampah dibuang ke sungai menimbulkan cemaran terhadap badan air dan pendangkalan sungai, sementara air sungai masih dimanfaatkan oleh masyarakat untuk kepentingan mandi. Efek buruk lain yang bisa ditimbulkan karena sampah dibuang ke sungai adalah masyarakat juga dapat menderita penyakit kulit karena menggunakan air yang tidak bersih dan sehat. Untuk menanggulangi pengelolaan sampah, masyarakat dapat membuat organisasi bank sampah. Sampah-sampah rumah tangga dipisahkan antara organik dan annorganik. Sampah organik atau mudah membusuk dapat dimanfaatkan sebagai kompos setelah diproses, sampah anorganik diubah menjadi barang lain yang bermanfaat dengan cara pemilahan dan merubah kebentuk lain. Sampah yang tidak dapat lagi digunakan menjadi barang lain dapat didaur ulang.

Sebagian besar masyarakat $(98,5 \%)$ tidak melakukan pengelolaan terhadap limbah cair rumah tangga. Masyarakat tidak memiliki SPAL di rumahnya, sehingga limbah kamar mandi dan dari dapur tidak dipisah. Limbah langsung dibuang ke halaman belakang, tidak melalui pengolahan terlebih dahulu, sehingga kadangkala menimbulkan genangan dan bau. Lingkungan tempat pembuangan limbah menjadi becek dan kotor. Genangan air mengundang lalat datang dan berkembang biak. Hasil analisa menunjukkan $p$ value $1,000>\alpha(0,05)$, artinya tidak terdapat hubungan signifikan antara pengelolaan limbah cair di rumah tangga dengan diare. Kondisi ini bertentangan dengan penelitian terdahulu yang menyimpulkan bahwa ada hubungan bermakna antara kepemilikan SPAL dengan penyakit diare. ${ }^{28}$

Fungsi dari SPAL rumah tangga adalah menyalurkan air dari kamar mandi, kegiatan mencuci, dan kegiatan lainnya dari dalam ke luar rumah. Saluran pembuangan harus tertutup. Saluran terbuka menyebabkan air kotor mencemari air bersih melalui rembesan ke tanah yang dilaluinya. Mengatasi hal ini, sebaiknya dibuatkan sumur resapan atau selokan umum untuk menampung air buangan dari rumah tangga di halaman, kebun, atau sawah. Air kotor hasil buangan tersebut yang mengandung mikroorganisme penyebab diare dapat masuk ke air bersih ataupun makanan. $^{28}$

Cara yang dapat dilakukan oleh keluarga dalam membuang limbahnya dalah melakukan pengelolaan air limbah. Air limbah yang dikelola, tidak akan menjadi tempat bersarangnya lalat maupun binatang vektor penyakit lainnya. Lingkungan juga akan terhindar dari bau dan gangguan estetika tentu jika sarana pembuangan air limbah memenuhi syarat. Dampak buruk lagi apabila tempat tersebut menjadi tempat perindukan nyamuk dan bersarangnya tikus, kondisi ini dapat berpotensi menularkan penyakit. Pada kelompok masyarakat yang tidak menerapkan STBM, terdapat 59,6\% menderita diare dan 50,4\% tidak diare sedangkan pada kelompok responden yang menerapkan STBM terdapat 28,8\% menderita diare dan $71,2 \%$ tidak menderita diare. Hasil uji menunjukkan $\mathrm{p}$ value $0,000<\alpha(0,05)$, artinya terdapat hubungan bermakna antara penerapan STBM dengan kejadian diare. Hasil ini diperkuat oleh 
penelitian tentang hubungan antara STBM dengan kejadian diare..$^{30,31}$

\section{SIMPULAN}

Penerapan pilar STBM merupakah faktor dominan yang menyebabkan diare, didukung pengetahuan baik dan tentu saja peran dari petugas kesehatan dalam memaparkan tentang pencegahan diare melalui penerapan pilar STBM. Perlu dilakukan strategi promosi kesehatan agar masyarakat menerapkan pilar STBM, salah satunya dengan pemicuan. Pengetahuan masyarakat mengenai informasi terbaru tentang pencegahan diare perlu ditingkatkan. Penelitian lanjutan dapat dilakukan berkaitan dengan model yang tepat dan efektif dalam penyampaian informasi kepada masyarakat dengan dukungan tokoh masyarakat.

\section{DAFTAR PUSTAKA}

1. Kemenkes RI P. Profil Kesehatan Indonesia 2018.; 2019. doi:10.1002/qj

2. Dinas Kesehatan Kabupaten Lampung Selatan. Profil Kesehatan Kabupaten Lampung Selatan. Dinas Kesehatan Kabupaten Lampung Selatan; 2019.

3. Puskesmas Rawat Inap Penengahan. Laporan Puskesmas Rawat Inap Penengahan. Puskesmas Rawat Inap Penengahan; 2019.

4. Priyoto. Perubahan Dalam Perilaku Kesehatan Konsep Dan Aplikasi. Graha Ilmu; 2015.

5. Kemenkes RI. Data Dan Informasi Profil Kesehatan Indonesia 2018. (Kurniawan R, Hardhana B, Yudianto, Siswanti T, eds.). Pusat Data dan Informasi Kementerrian Kesehatan Republik Indonesia; 2019.

6. Jensen, A D, Danyluk, et al. Quantifying the Effect of Hand Wash Duration, Soap Use, Ground Beef Debris, and Drying Methods on the Removal of Enterobacter aerogenes on Hands. J Food Prot. 2015;78(4):685-690. doi:10.4315/0362-028x.jfp14-245

7. Tartari E, Pires D, Pittet D. Clean Your Hands May 5, 2017: Fight Antibiotic Resistance-It's in Your Hands. Infect Control Hosp Epidemiol. 2017;38(4):499. doi:10.1017/ice.2017.43

8. Cassivi A, Dorea CC, Johnston R, Waygood EOD. Access to drinking water: Time matters. $J$ Water Health. 2018;16(4):661-666. doi:10.2166/wh.2018.009

9. Infodatin. Perilaku Mencuci Tangan Pakai Sabun di Indonesia. Published online 2014:7.

10. Husna A, Rahmi N. Hubungan Pengetahuan dan Sikap Ibu dengan Kejadian Diare pada Balita di Wilayah Kerja Puskesmas Delima Kecamatan Delima Kabupaten Pidie Tahun 2015. J Healthc Technol Med. 2016;2(2):Hal. 171-177. doi:10.33143/jhtm.v2i2.250

11. Hartati S, Nurazila N. Faktor Yang Mempengaruhi Kejadian Diare Pada Balita Di Wilayah Kerja Puskesmas Rejosari Pekanbaru. $J$
Endur.

2018;3(2):400.

doi:10.22216/jen.v3i2.2962

12. Hastuty M, Utami SN. Hubungan Pengetahuan Ibu dengan Kejadian Diare pada Balita di Kelurahan Bangkinang Kota Wilayah Kerja Puskesmas Bangkinang Kota Tahun 2017. J Doppler Univ Pahlawan Tuanku Tambusi. 2017;8(1):Hal. 32-47.

13. Arsurya Y, Rini EA, Abdiana A. Hubungan Tingkat Pengetahuan Ibu tentang Penanganan Diare dengan Kejadian Diare pada Balita di Kelurahan Korong Gadang Kecamatan Kuranji Kota Padang. J Kesehat Andalas. 2017;6(2):452. doi:10.25077/jka.v6i2.720

14. Rohmah S. Pengaruh Paparan, Lingkungan, Tokoh Masyarakat, dan Tenaga Kesehatan terhadap Partisipasai dalam Desa Siaga. J Kesehat Bakti Tunas Husada J Ilmu-ilmu Keperawatan, Anal Kesehat dan Farm. 2019;19(1):Hal. 133149. doi:10.36465/jkbth.v19i1.460

15. Bahri L. Faktor-faktor yang berhubungan dengan Perilaku Cuci Tangan Pakai Sabun pada Siswa DN di Kecamatan Simpang Pematang Kabupaten Mesuji, Provinsi Lampung. J Ilmu Kesehat Masy Indones. 2020;1(1).

16. Lidiawati M. Hubungan Sanitasi Lingkungan Dengan Angka Kejadian Diare Pada Balita Di Wilayah Kerja Puskesmas Meuraxa Tahun 2016. J Serambi Saintia. 2016;4(2):1-9.

17. Silalahi N, Sinambela RY. Analisis Hubungan Sanitasi Total Berbasis Masyrakat (STBM) Dengan Kejadian Diare Pada Balita Di Desa Suka Mulia Kecamatan Hinai Kabupaten Langkat. $J$ Penelit Kesmasy. 2020;2(2):Hal. 9-18.

18. Mukti D, Raharjo M, Dewanti N. Hubungan Antara Penerapan Program Sanitasi Total Berbasis Masyarakat (Stbm) Dengan Kejadian Diare Di Wilayah Kerja Puskesmas Jatibogor Kabupaten Tegal. J Kesehat Masy Univ Diponegoro. 2016;4(3):767-775.

19. Syam S, Asriani A. Penerapan Sanitasi Total Berbasis Masyarakat (Stbm) Pilar 1 Stop Buang Air Besar Sembarangan (Stop Babs) Dengan Kejadian Penyakit Diare Di Kelurahan Lakkang Kecamatan Tallo Kota Makassar. Sulolipu Media Komun Sivitas Akad dan Masy. 2019;19(1):109. doi:10.32382/sulolipu.v19i1.1035

20. Agustina Aat. Promosi Kesehatan. Modul Bahan Ajar Cetak Keperawatan. 2019;136(1):13. doi:10.1109/IECON.2012.6388590

21. Spears D, Ghosh A, Cumming O. Open Defecation and Childhood Stunting in India: An Ecological Analysis of New Data from 112 Districts. PLoS One. 2013;8(9). doi:10.1371/journal.pone.0073784

22. Cherian V, Sahu M. Open Defecation: A Menace to Health and Dignity. Indian J Public Heal Res Dev. 2016;7(4):85. doi:10.5958/09765506.2016.00195.9

23. Ahyanti M, Rosita Y, Yushananta P. Utilisation of 
the family latrine post declaration ODF. Int $J$ Innov Creat Chang. 2020;13(2):192-204.

24. Yushananta P, Usman S. The Incidence of Diarrhea in Babies Affected through the Cleanliness of Eating Utensils and Hands. J Med Sci Clin Res. 2018;6(9):Hal. 790-794. doi:10.18535/jmscr/v6i9.137

25. Ikrimah I, Maharso M, Noraida N. Hubungan Pengelolaan Air Minum dan Makanan Rumah Tangga Dengan Kejadian Diare. $J$ Kesehat Lingkung J dan Apl Tek Kesehat Lingkung. 2019;15(2):655. doi:10.31964/jkl.v15i2.134

26. Sumolang PPF, Nurjana MA, Widjaja J. Analisis Air Minum dan Perilaku Higienis dengan Kejadian Diare pada Lansia di Indonesia. Media Penelit dan Pengemb Kesehat. 2019;29(1):Hal. 99-106. doi:10.22435/mpk.v29i1.123

27. Hairani B, Suriani S, Andiarsa D, Juhairiyah J. Hubungan pengetahuan ibu tentang diare dan perilaku memasak air minum dengan kejadian diare balita di Puskesmas Baringin Kabupaten Tapin tahun 2014. J Heal Epidemiol Commun Dis. 2019;3(1):10-14. doi:10.22435/jhecds.v3i1.1808

28. Mukti DA, Raharjo M, Dewanti NAY. Hubungan Antara Penerapan Program Sanitasi Total
Berbasis Masyarakat (Stbm) Dengan Kejadian Diare Di Wilayah Kerja Puskesmas Jatibogor Kabupaten Tegal. J Kesehat Masy. 2016;4(3):Hal. 767-775.

29. Syahrizal. Hubungan penanganan sampah dengan kejadian diare di wilayah kerja Puskesmas Ingin Jaya Kabupaten Aceh Besar. J Ilm Kesehat Nasuwakes. 2016;9(1):Hal. 69-75.

30. Yusran Y. Pelaksanaan Program STBM Stop BABS di Desa Lembur Timur dan Desa Luba Kecamatan Lembur Kabupaten Alor tahun 2015. J Kesehat Lingkung. 2017;9(2):163-171.

31. Surya J. Sanitasi Total Berbasis Masyarakat (STBM Dengan Diare Pada Balita. J Ilm Kesehat Sandi Husada. 2019;10(2):281-284. doi:10.35816/jiskh.v10i2.169

(7) (C) (2022. This open-access article is distributed under the terms and conditions of the Creative Commons Attribution-ShareAlike 4.0 International License. 